\title{
2. TEXTURES, MICROSTRUCTURES, AND LITHOLOGIES OF JAPAN SEA SEDIMENTS FROM THE LOWER PORTION OF HOLE 799B, LEG $128^{1}$
}

\author{
John R. Griffin ${ }^{2}$ and Nancy Lindsley-Griffin ${ }^{2}$
}

\begin{abstract}
Textures, microstructures, and major lithologies of samples from 750 to $1081 \mathrm{mbsf}$ of Hole 799B, Leg 128, Japan Sea, were studied in 40 thin sections. The study provided evidence for the sequence of diagenetic mineralization for the lower portion where the sediments become well-lithified. The diagenetic sequence for the lower portion of Hole $799 \mathrm{~B}$ revealed from crosscutting relationships in textures and structures is (1) hard, round, "D-phosphate" nodules and glauconite grains transported and deposited with the sediments; (2) "F-phosphate" streaks and pyrite framboids; (3) clay minerals; (4) rotation, flattening, and compaction; and (5) irregular glauconite grains. Fabric that has been defined by the subparallel to parallel optical orientation of clay minerals becomes more pronounced with increasing depth. Compaction enhances clay mineral fabric by flattening soft F-phosphate nodules, burrows, and microfossils (like the sponge Sagarites makiyama or Makiyama titanni).
\end{abstract}

\section{INTRODUCTION}

Forty samples collected from Hole 799B (Figs. 1 and 2) were examined petrographically for textures and microstructures that might bear on the origin and history of Japan Sea sediments. Samples were collected as hard chips where sediments were lithified; otherwise, small plastic boxes were used to collect an undisturbed cube of sediment.

The emphasis of this petrographic study is the sedimentary record of the lower portion of Hole 799B from 750 to 1081 mbsf (meters below sea floor). Sediments have undergone a change from poorly lithified to well-lithified in the lower interval of Hole 799B. The petrographic study provides observations of diagenetic sequence as well as of development of early structural features. Samples used (Fig. 2) are from the lower portion of lithologic Units III, IV, and V, which were defined in the lithostratigraphy portion of the Site 799 chapter, p. 260-265, Leg 128 Initial Reports (Shipboard Scientific Party, 1990b). The samples studied here range in age from middle to early Miocene (Shipboard Scientific Party, 1990b, p. 260-265).

\section{Preparation of Thin Sections}

Lithified sediments were cut into thin sections using standard techniques. Partially lithified sediments were impregnated with epoxy and allowed to harden before being cut into thin sections. Impermeable unlithified sediments were hardened with a low-viscosity resin, using the techniques described by Swartz and Lindsley-Griffin (1990) and then were cut into thin sections 40 to $50 \mu \mathrm{m}$ thick. A greater thickness of sections was necessary because soft sediments have a tendency to pluck and grind unevenly, even when impregnated.

Although blue-dyed epoxy was used to impregnate many of the thin sections in an attempt to determine original porosity, results were ambiguous because the extremely low permeability of the rocks resulted in uneven impregnation. Most thin sections also were treated with Alizarin-red stain to distinguish between calcite and dolomite.

\section{LITHOLOGIES OF HOLE 799B}

Most of the samples we studied are siliceous claystones and mudstones containing variable amounts of silt (Appendix). Minor lithologies studied include porcellanite, carbonate, and sandstone. All of the


ODP, Sci. Results, 127/128, Pt. 1: College Station, TX (Ocean Drilling Program).

${ }^{2}$ Department of Geology, 214 Bessey Hall, University of Nebraska, Lincoln, NE 68588-0340, U.S.A. samples, except a few without clay minerals, exhibit a fabric defined by optically subparallel orientations of clay minerals and laminae of phosphate nodules and pyrite framboids. Many of the samples also display bedding that has been defined by concentrations of silt and sand grains, or concentrations of diagenetic silica or carbonate.

\section{Siliceous Pelites and Porcellanites}

Most of the lithologies in the interval studied are siliceous pelites (Pl. 1, Fig. 1). These include clay-rich pelite, silica-rich pelite, and porcellanite. Clay-rich pelite consists dominantly of isotropic to subisotropic diagenetic silica and microcrystalline clay in roughly equal proportions. Silica-rich pelite is composed of isotropic to subisotropic diagenetic silica, with minor microcrystalline clay. Porcellanites, defined as well-indurated rocks that consist of $50 \%$ to $75 \%$ diagenetic silica (Shipboard Scientific Party, 1990a, p. 49), occur as finely laminated to thinly bedded small concretions within the siliceous claystones and mudstones. These porcellanites, like the silicarich pelites, consist of isotropic to subisotropic diagenetic silica, with minor microcrystalline clay; however, they are much more indurated than the silica-rich pelites and cannot be scratched by a steel needle. One of the most interesting porcellanites in Hole 799B (Pl. 1, Fig. 2) is composed of silica pellets in a siliceous claystone matrix that is associated with phosphatic pelagic debris.

Authigenic minerals in the pelites include framboidal pyrite and phosphate in both nodular and dispersed forms. Silt-size and rare sand-size clastic grains are ubiquitous in the siliceous pelites, but they typically make up less than $10 \%$ of the volume (Pl. 1, Fig. 1). Clastic grains are angular to subangular, rarely subround, and consist mainly of quartz. Minor clastic components include feldspar, glauconite, rock fragments (claystone, siltstone), calcareous and siliceous microfossils, and D-phosphate nodules.

\section{Silty Pelites}

As depth increases within the studied interval of Hole 799B, the amount of diagenetic silica appears to decrease along with an increase in proportion of clay minerals. Other components of these rocks are similar to those of the siliceous pelites, except that the amount of carbonate increases. These rocks are best described as silty claystones and mudstones.

\section{Sandstones}

Among the samples studied, several consist of fine- to mediumgrained, subangular to angular, poorly sorted sandstone and silty sand- 


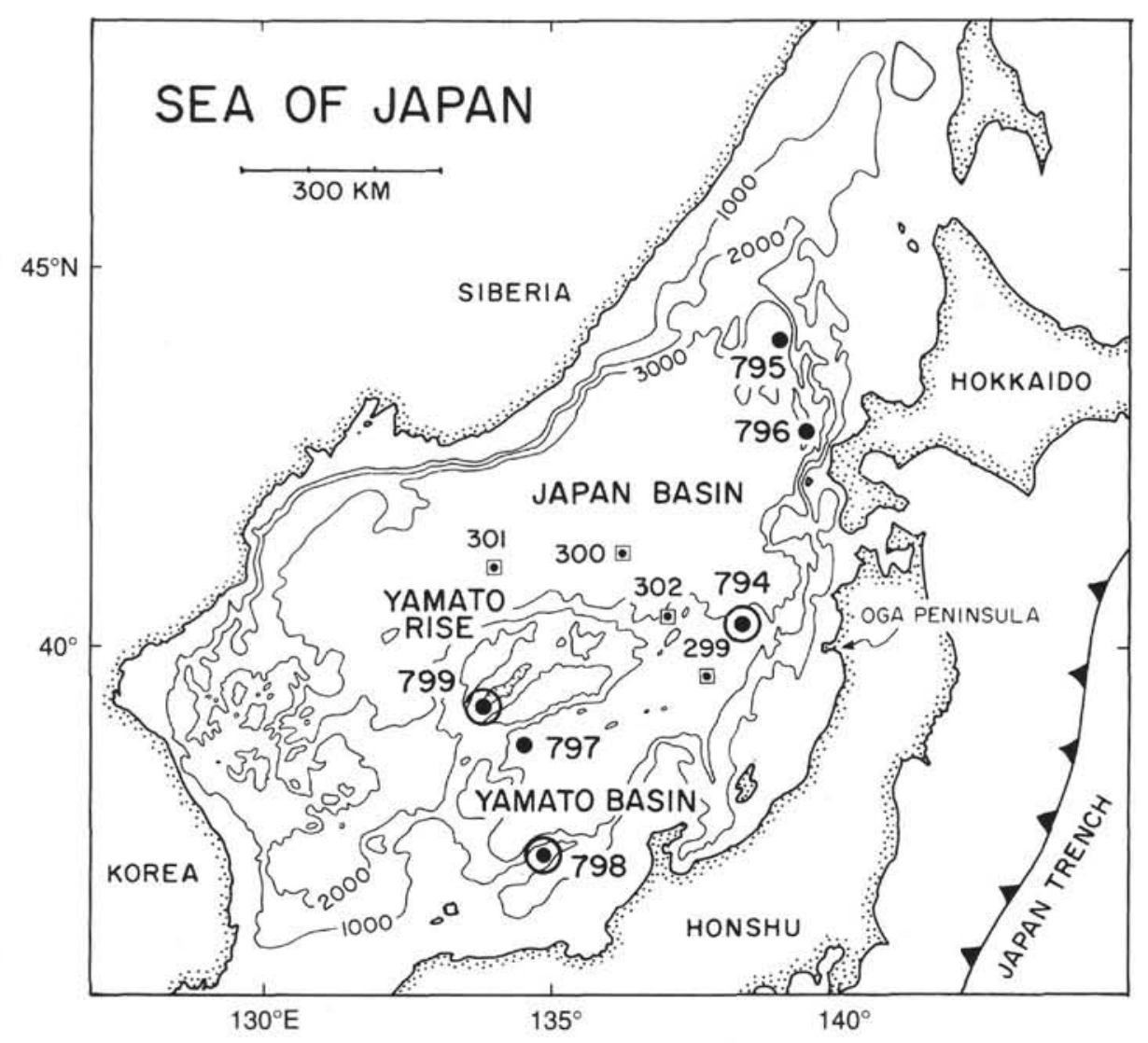

Figure 1. Location map of Japan Sea. Site 799 is at the southwestern end of the Yamato Rise.

stone (Pl. 1, Fig. 3). Several of the pelitic samples also contain thin interbeds of silty sandstone. The major clastic component of these sandstones is quartz; minor constituents include feldspar, glauconite, chlorite, pyritic "F-phosphate," silica nodules, and hard phosphate nodules. Rock fragments include siltstone (some containing pyrite framboids), claystone, chlorite schist, dolomite, phosphatic claystone, pelletal phosphate, pyritic phosphate, porcellanite, volcanic glass (some with flow banding), and quartzite (metamorphic fabric of recrystallized, sutured quartz grains). Dark brown to black, fibrous organic material that is probably plant debris is present in two of the samples.

Sandstone Sample 128-799B-65R-2, 145-147 cm, 1061.35 mbsf, has a carbonate cement. Sample 128-799B-61R-4, 55-57 cm, $1024.85 \mathrm{mbsf}$, from the thick turbidite sand between 1019.8 and $1026.02 \mathrm{mbsf}$, has been cemented by dark brown to black isotropic silica. The porosity of this sandstone has been greatly reduced and is marked by an increase in resistivity and sonic velocity that was recorded in the electric logs (p. 338 and Fig. 139 in Shipboard Scientific Party, 1990b).

\section{"Vitric Tuff"}

In the interval from 981.17 to $1002.41 \mathrm{mbsf}$ (Fig. 3), $6.71 \mathrm{~m}$ of "altered vitric tuff," "vitric tuff," and "tuff breccia" was recovered (Shipboard Scientific Party, 1990b, p. 287). Wireline logs indicate a region of higher total gamma, higher thorium, and reduced resistivity at the interval from 982 to 1009 mbsf, which is the tuffaceous zone (Fig. 4). Logs indicate that this tuffaceous zone consists of three separate layers of tuffaceous material that has been divided by two sedimentary layers of minor thickness (p. 287, Shipboard Scientific Party, 1990b).

Our study of samples, from the interval 981.17 to $1002.41 \mathrm{mbsf}$, shows considerable lithologic variation of the "altered vitric tuff" and much reworking of tuffaceous material. Sample 128-799B-57R-1,
75-77 cm (Appendix), is a siliceous claystone that contains significant amounts of authigenic phosphate $(5 \%)$ and pyrite framboids $(3 \%)$. The matrix is clay rich with patches of isotropic silica that may have been altered volcanic glass.

Sample 128-799B-58R-1, 13-15 cm (Appendix), is a silty porcellanite containing 9\% clastic silt (Pl. 1, Fig. 4) as well as authigenic dolomite $(3 \%)$, phosphate $(1 \%)$, and framboidal pyrite $(1 \%)$. However, the presence of clastic biotite and a nonframboidal opaque mineral (magnetite?) in the latter sample suggests that the original sediment may have contained a significant component of reworked volcanic material. In the case of the former sample, the absence of silt and the preponderance of silica suggest that the sediment has been derived from reworking of volcanic ash.

Sample 128-799B-58R-1, 62-64 (Appendix) is a dolomitic porcellanite that could have originated from alteration of a tuff. It consists of $60 \%$ isotropic to subisotropic silica and $39 \%$ silica mixed with microcrystalline carbonate (dolomite?). However, even this sample contains trace amounts of silt (quartz and feldspar) and authigenic phosphate, Appendix), suggesting a mixing with minor terrigenous component and reworking of an altered vitric tuff.

Sample 128-799B-59R-1, 50-52 (Appendix) is an altered vitric tuff containing subisotropic silica that is probably devitrified glass. It has rare shards.

\section{FOSSILS}

Fossils are sparse in thin section from the lower portion of Hole 799B. In the upper parts of the section studied, rare "ghosts" of diatoms are visible and typically consist of amorphous silica that has been outlined by pyrite framboids. According to the Site 799 Summary for Leg 128 (Shipboard Scientific Party, 1990b, p. 302, 305), radiolarians and diatoms were sparse and or poorly preserved in the lower interval of Hole 799B because this portion of the hole is below 


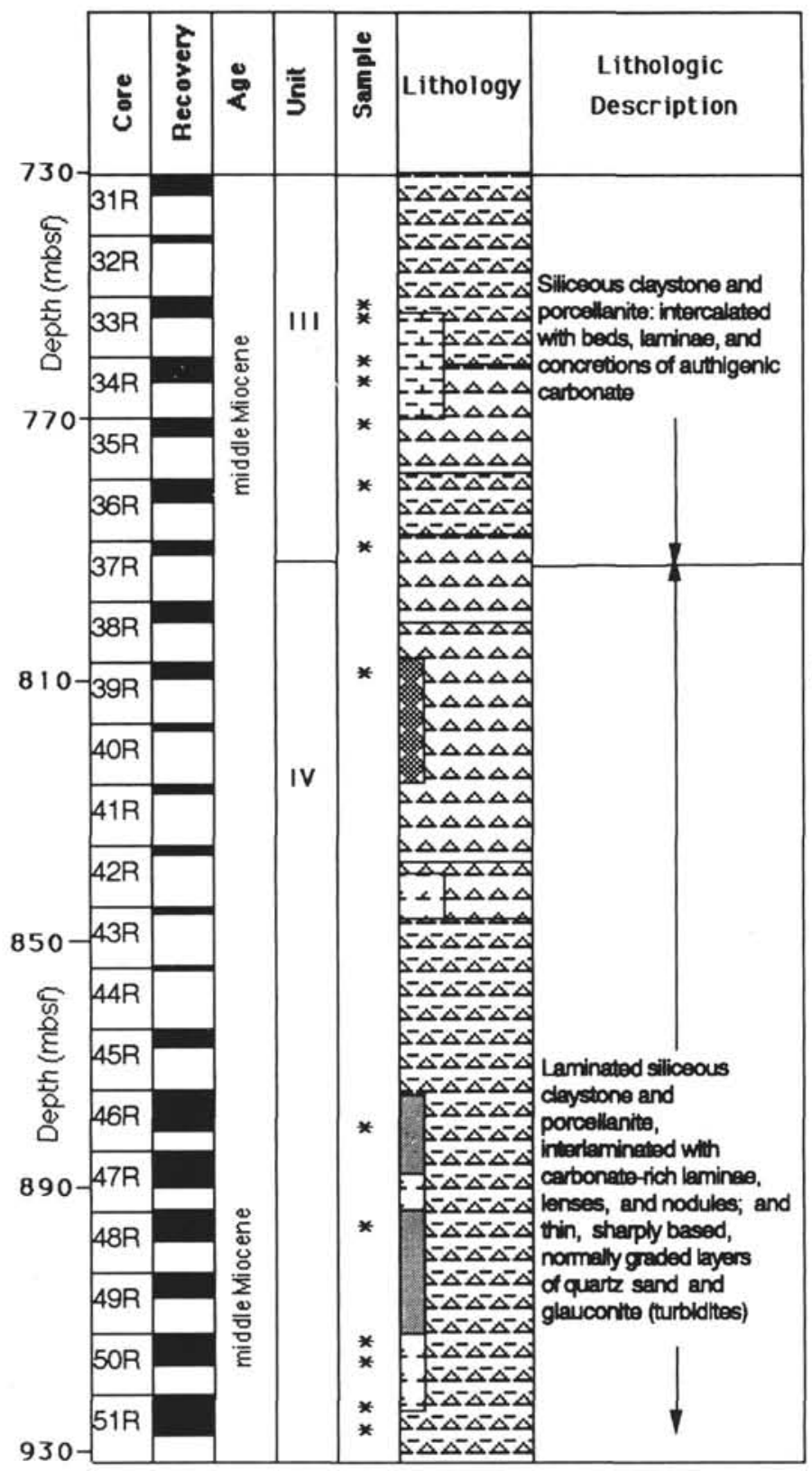

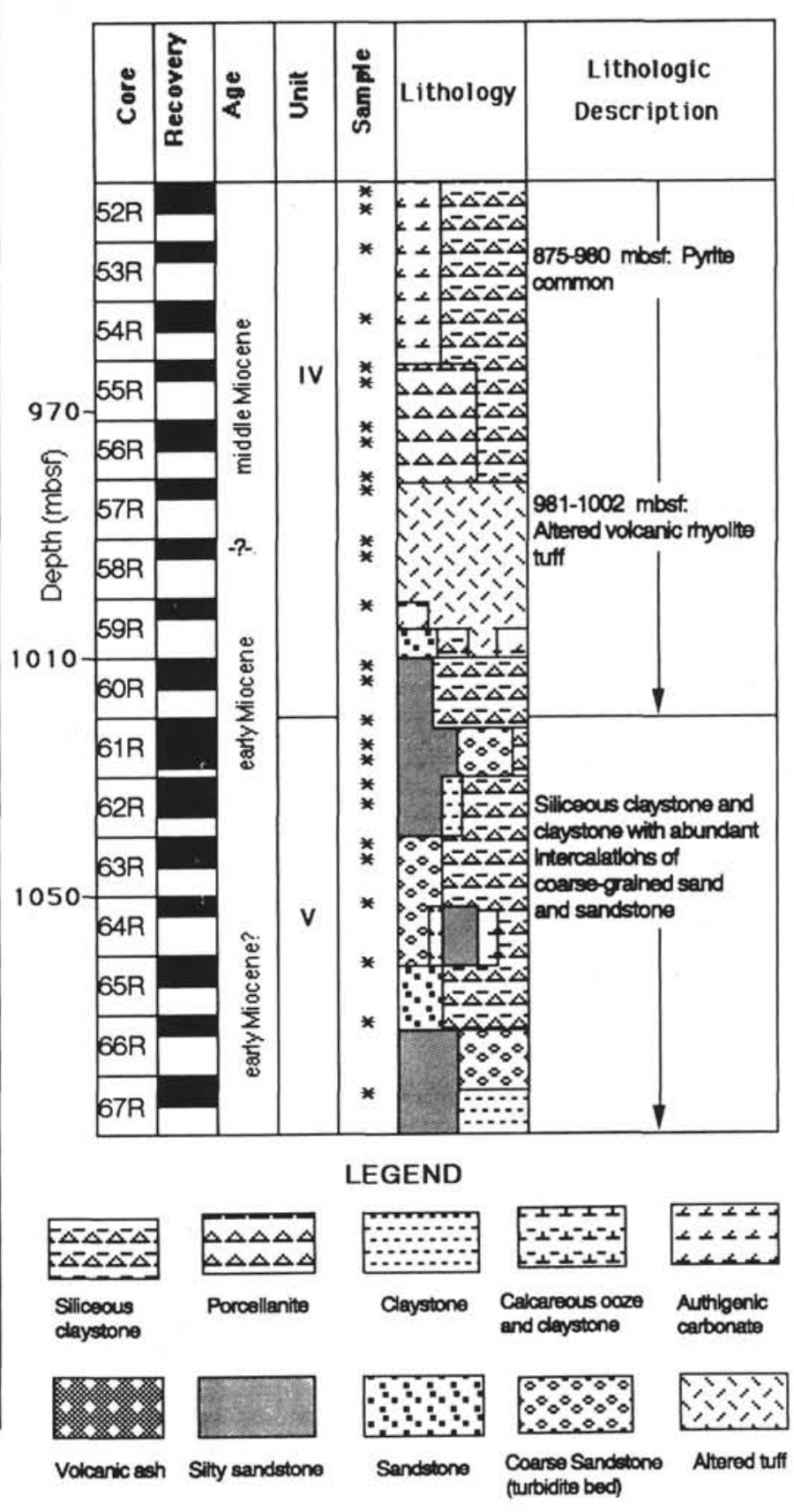

Figure 2. Lithologic log of lower portion of Hole 799B and location of thin sections studied in this report. Modified after Figure 1 in the "Site 799" chapter of Initial Reports volume (Shipboard Scientific Party, 1990b).

the opal A/opal CT and opal CT/diagenetic quartz boundaries (Shipboard Scientific Party, 1990b, p. 278, 280).

Within the lower, more lithified material of Hole 799B, a number of flattened donut-shaped fossils occur (Pl. 2) that have been tentatively identified from photomicrographs as Sagarites makiyama (or Makiyama titanni) by Ryuji Tada (pers. comm., 1990). The internal cavities of these sponges are readily visible (Pl. 2, Figs. 1 and 2). A well-preserved fossil sponge in Sample 128-799B-53R-CC, 9-11 cm, exhibits internal spicules (Pl. 2, Figs. 3 and 4). These sponges were observed in a number of different orientations and degrees of preservation between 935.30 and 1069.36 mbsf. In the lowermost portion of Hole 799B, they have been intensely crushed and recrystallized; even at shallower depths, these sponges have been flattened by compaction. Typically, the sponges are rimmed with concentrations of phosphate- and silica-enriched pelite, and some are outlined by pyrite framboids. An incomplete row of silt grains around one of the sponges in Sample 128-799B-53R-CC, 9-11 cm, may be a relict rim of agglutinate (PI. 2, Fig. 2). Their internal cavities also are enriched in authigenic phosphate.

\section{DIAGENETIC MINERALS Clays}

Clay minerals increase in grain size in the deeper portion of the hole, indicating growth of clays with continuing diagenesis. All samples exhibit a fabric defined by optical alignment of the long axes of clay minerals. This preferred orientation of clay particles also increases with depth. Clays in samples from the shallower depths of Hole 799B exhibit long crystal axes subparallel to bedding; at deeper levels, the parallelism of clay particles to bedding orientation in- 


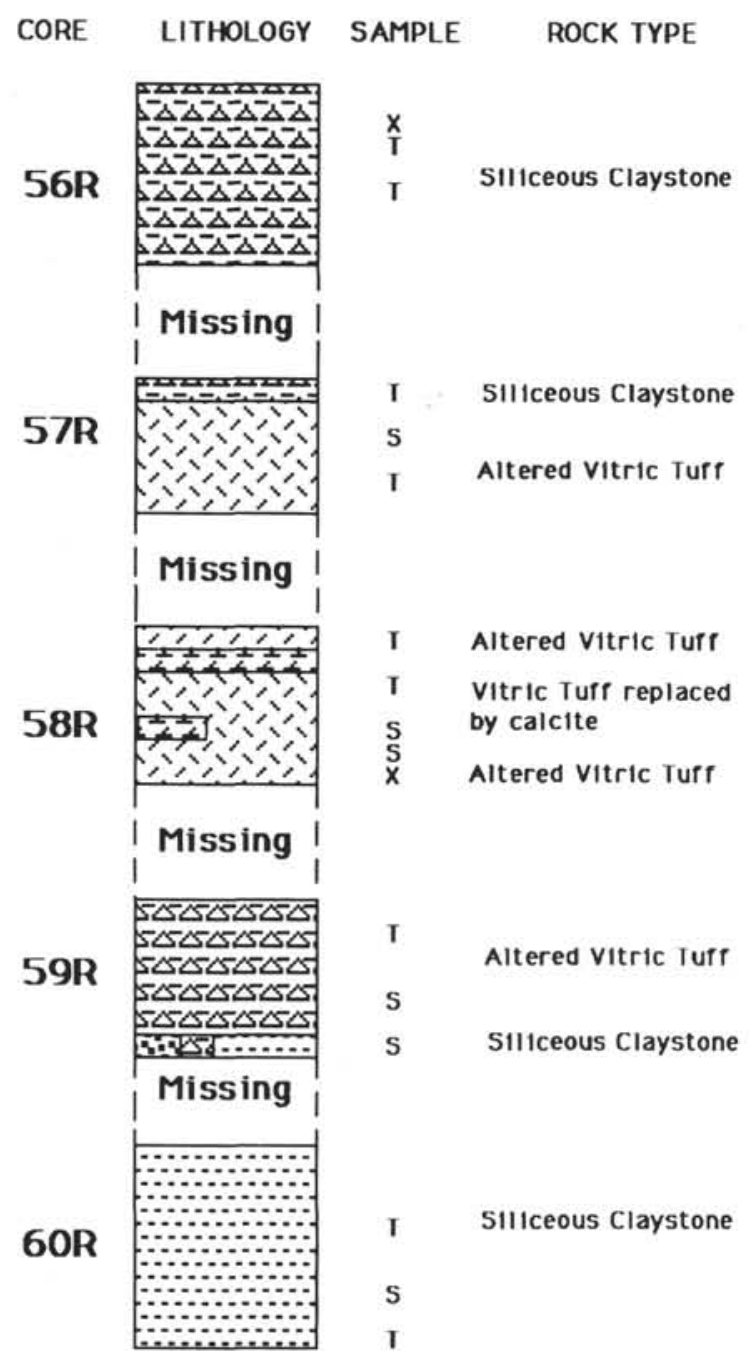

Figure 3. Lithology log and sample data for "altered tuff" section, Hole 799B. Symbols used: $\mathrm{T}$ - location of thin section studied in this report; $\mathrm{S}$ - location of shipboard smear slides; X-location of shipboard XRF analyses. Modified after core barrel descriptions, p. 633, 634 in the "Site 799" chapter of Initial Reports volume (Shipboard Scientific Party, 1990b).

creases. This preferred orientation is readily apparent in thin section when the stage is rotated to a position of $45^{\circ}$ with nicols crossed and gypsum plate in, as the clay minerals in parallel optic orientation assume the same interference color.

\section{Silica}

The depth of the opal A/opal CT transition at Site 799 occurs over an interval of approximately $50 \mathrm{~m}$. Smear slide identifications and XRD analysis indicate that the opal A/opal CT transition at Site 799 occurs between 414 and 457 mbsf (Shipboard Scientific Party, 1990b, p. 278). The opal CT/quartz transition occurs over an interval from 545 to 585 mbsf (Shipboard Scientific Party, 1990b, p. 280).

Although all the samples we studied are from depths of 750 to $1081 \mathrm{mbsf}$, well below the reported opal CT/quartz transition, the silica in our samples is not crystalline quartz. Silica in these rocks is seen as isotropic to subisotropic hazy clouds, with no microscopically visible crystallinity (Pl. 1, Fig. 1). Thus, diagenetic silica is still poorly organized at these depths and is cryptocrystalline.

The pelitic rocks at these depths range from a clay-rich pelite, composed of roughly equal proportions of microcrystalline clay and diagenetic silica; to clay-bearing siliceous pelite, composed mostly of silica, with about $30 \%$ microcrystalline clay; to silica-rich pelite, composed of diagenetic silica, with minor microcrystalline clay. Layers of virtually pure silica occur locally in porcellanites. A clayfilled fracture or vein parallel to the bedding is surrounded by a reddish-brown siliceous solution front in Sample 128-799B-50R-3, $74-76 \mathrm{~cm}$. In many samples, burrows have been filled with cloudy subisotropic silica (PI. 3, Fig. 1) or with cloudy silica stained with dark grayish-brown organic material (PI. 3, Fig. 2).

\section{Pyrite}

Pyrite is ubiquitous in all lithologies as fine framboidal specks and clots (Pl. 3, Fig. 1). Many samples, especially in the shallower parts of Hole 799B, also exhibit stringers and flattened nodules of pyrite framboids (Pl. 3, Fig. 1). Isolated pyrite framboids also occur in the siliceous or carbonate cements of sandstones. One sandstone has been cemented by framboidal pyrite (Pl. 3, Fig. 3). Pyrite framboids also are concentrated within "F-phosphate" nodules and tend to be most common in the phosphate-enriched layers. Framboidal pyrite fills the interiors of some microfossils. Many microfossils, including the tiny sponges (PI. 2), are rimmed by pyrite framboids; some microfossils have been replaced by pyrite (Pl. 3, Fig. 4). Some, but not all, glauconite grains exhibit framboidal pyrite in their cores (Pl. 4, Fig. 1).

\section{Phosphates}

Dissolved phosphate in interstitial waters of Site 799 was observed to increase to a maximum at $28 \mathrm{mbsf}$, and then to steadily decrease to near zero at $320 \mathrm{mbsf}$ (Shipboard Scientific Party, 1990b, p. 318). The interstitial-water chemistry suggests that phosphate precipitates and is stable within the sediment column below 320 mbsf. Our petrographic observations support this interpretation. Phosphate was present in all the samples we studied in the interval from 750 to 1080 mbsf. In thin section, phosphatic material can be seen to occur in many different forms: fragments of fish bone and teeth, peloids, rims or fillings in microfossils, phosphate nodules, and dispersed clouds and streaks.

Amounts of phosphate that we determined by thin-section point counts (Appendix) range from $1 \%$ to as much as $15 \%$; most samples of siliceous pelites contain $3 \%$ to $4 \%$ of phosphatic material. Values of $\mathrm{P}_{2} \mathrm{O}_{5}$ obtained by X-ray fluorescence for Hole 799B, are $0.09 \%$ (128-799B-39R-1, $86 \mathrm{~cm}), 0.15 \%$ (128-799B-51R-3, $59 \mathrm{~cm})$, and $0.12 \%$ (128-799B-61R-6, $4 \mathrm{~cm}$ ), as reported in Table 4 of the Site 799 chapter (Shipboard Scientific Party, 1990b, p. 293).

Microscopic fragments of pelagic debris, mostly fish teeth and bones, are found in trace amounts in all lithologies except the sandstones. These pelagic phosphates are distinguished by their skeletal, curved shapes (Pl. 1, Fig. 2), as well as by their sharp margins, moderate to high relief, and clear, crystalline appearance (PI. 3, Fig. 2). Their colors are typically brighter than those of other forms of phosphate and range from bright yellow to orange to scarlet or reddish-brown. Within the portion of Hole 799B that we studied, fish fragments were reported previously at only one depth: the smear slide at $875.7 \mathrm{mbsf}$ (Sample 128-799B-46R-1, $42 \mathrm{~cm}$ ), according to the barrel sheets from the Initial Reports volume (Shipboard Scientific Party, 1990b, p. 624).

Peloidal phosphates were rarely observed, perhaps because they can be only distinguished with certainty if they exhibit pelletal or concentric structure (Pl. 4, Figs. 1 and 3). In these rocks, the peloidal phosphate is typically yellowish-brown to reddish-brown, with sharp boundaries and high relief.

Phosphatic material appears to rim or fill many microfossils, especially the internal cavities and outer margins of the sponges (Pl. 2). This phosphatic material is not as pure as the "F-phosphate" nodules described below, but it consists of silica or siliceous claystone enriched with phosphate to produce the typical reddish-brown color and birefringence of the "F-phosphates." 


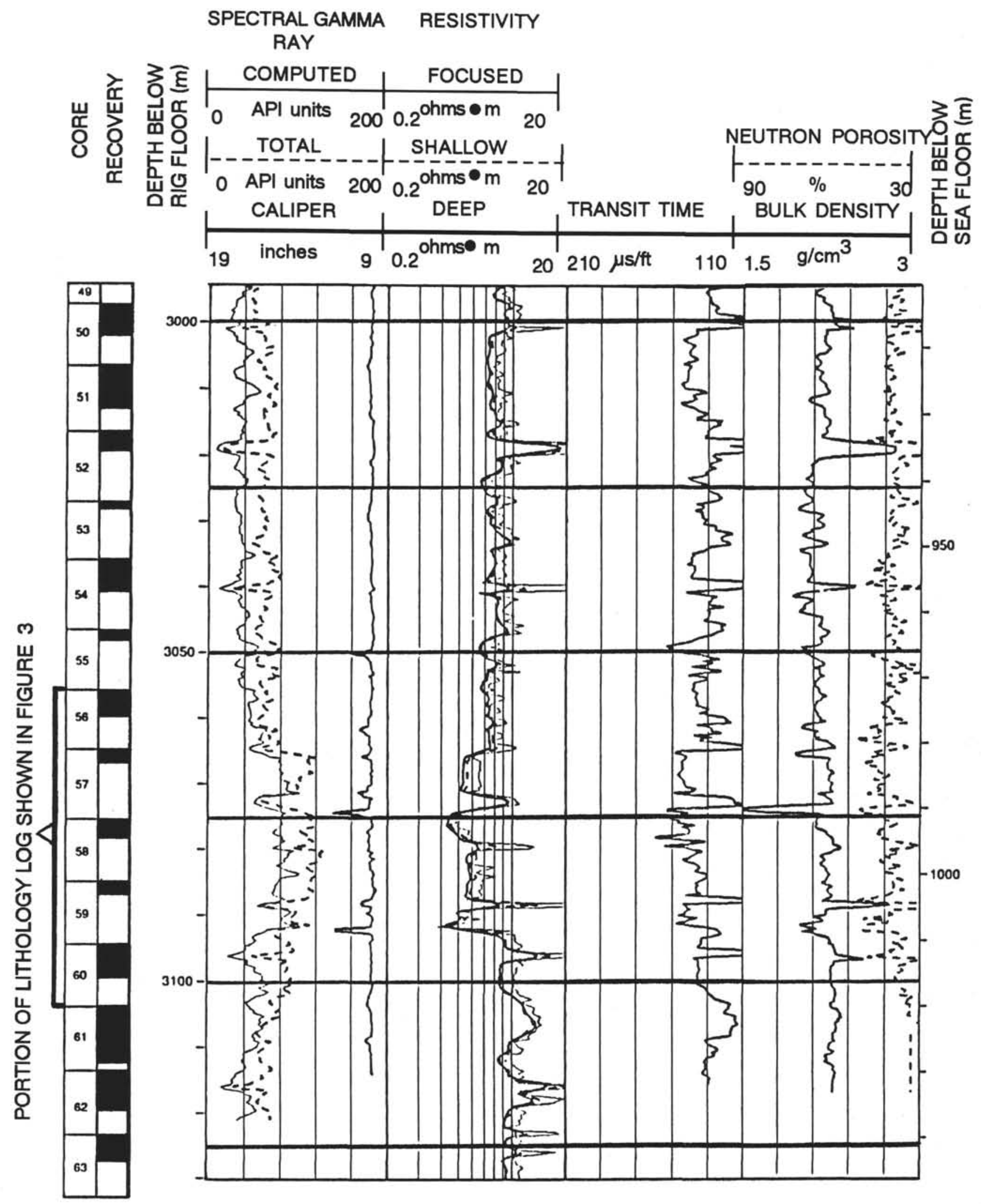

Figure 4. Wireline log of "altered tuff" section, Hole 799B. Modified after unpublished wire line data reduction by Borehole Research Group, Lamont-Doherty Geological Laboratory. 
The features we term "D-phosphates," following the classification of types of phosphatic material of Garrison and Kastner (1990), are dense, hard silt or sand-sized nodules (Pl. 4, Fig. 2) analogous to the much larger "D-phosphate" nodules of the Peru margin, described by Garrison and Kastner (1990). These yellowish-brown to dark, reddish-brown micro-nodules are round or oblong and have sharp grain boundaries and high relief. "D-phosphates" are typically clear and crystalline in appearance. They must have been well-indurated before they were incorporated into the sediments because they retain their original shape, rather than having been flattened during compaction. In Hole 799B, the allochthonous "D-phosphates" are typically associated with silt or sand grains of mineral and rock fragments, with which they must have been transported.

In contrast to the "D-phosphates," the features we term "F-phosphates," following the classification of types of phosphatic material of Garrison and Kastner (1990), are flattened, friable concentrations of impure phosphate, with fuzzy, indistinct boundaries that commonly merge into the claystone or carbonate matrix (Pl. 4, Fig. 4). These "F-phosphate" nodules typically are associated with framboidal pyrite clots and stringers and contain a substantial amount of pyrite within their boundaries. These microscopic "F-phosphates" are considered to be analogous to the "F-phosphate" nodules of Garrison and Kastner (1990) because of their similar occurrence and morphology. We consider the "F-phosphate" nodules in Hole 799B to be autochthonous, rather than having been transported, because of their irregular gradational boundaries with the surrounding matrix (Pl. 4, Fig. 4). Additional evidence supporting in-situ formation of "F-phosphates" was found by their response to compaction: typically, these nodules are flattened and elongated in the plane of bedding (Pl. 4, Fig. 4), and at greater depths within Hole 799B, the "F-phosphate" nodules have been crushed and bent into shapes that conform to the surrounding grains (Pl. 5, Fig. 1).

Dispersed clouds, streaks, and fuzzy, diffuse patches of reddishbrown, phosphate-enriched silica that merge imperceptibly with the matrix are ubiquitous in the pelites. The dark patch surrounding the fish debris in Plate 4, Figure 2, is such a phosphatic concentration. Locally, these poorly organized proto-nodules grade into betterorganized "F-phosphate" nodules.

Siliceous claystones and mudstones typically contain examples of all of the forms of phosphate described above. However, in the porcellanites, most phosphate occurs as dispersed clouds and streaks of phosphatic silica and clay that merge indistinctly with the matrix; "F-phosphate" nodules and "D-phosphate" nodules are rare to absent in porcellanites.

\section{Carbonate}

Carbonate, mostly dolomite, occurs as cement in one sandstone (Sample 128-799B-65R-2, 145-147 cm). In the pelites, carbonate mixed with cloudy diagenetic silica occurs locally as laminae and as burrow fills. Small concretions of carbonate-rich and siliceous pelites occur in several samples. These are typically elongate or flattened parallel to bedding (Pl. 5, Fig. 2). A group of two or three foraminifers forms the core of a small calcareous concretion in Sample 128-799B$61 \mathrm{R}-5,80-82 \mathrm{~cm}$ (Pl. 5, Fig. 3).

\section{Glauconite}

Glauconite most commonly occurs as subangular to subrounded grains within silt and sand beds of probable turbidite origin. Glauconite is also present in trace amounts as silt-sized subangular to subrounded grains that have been dispersed throughout the silt-bearing pelites. Most of this glauconite was probably reworked and transported, but unequivocal evidence for its origin is difficult to find. The glauconite is typically yellowish-green to grass green, but some grains exhibit brownish rims, suggesting that they have been weathered. Grains that retain only a portion of brown rim probably represent weathered grains that were broken during transport, as seen in Plate 4, Figure 1.

Glauconite that can be demonstrated to have formed in-situ is rare. One example has an olive green core of peloidal glauconite that contains a pyrite framboid and is surrounded by an irregular overgrowth of bright green glauconite in a different optical orientation. Clay minerals that adjoin the glauconite have been rotated into subparallelism with the grain boundary, suggesting that they were pushed outward, while glauconite grew in place. In the absence of such evidence for in-situ growth, we have interpreted most of the angular to subangular silt-sized grains of glauconite as transported clasts.

\section{Organic Carbon}

Most of the sediments and sedimentary rocks from Site 799B contain abundant total organic carbon, $0.24 \%$ to $5.66 \%$ (Shipboard Scientific Party, 1990b, p. 323). The only organic material that we identified petrographically is fibrous, dark brown to black material, probably plant debris, in Sample 128-799B-61R-4, 55-57 cm. However, brown-stained silica in several samples may have been contaminated with organic material, and much of the dark cryptocrystalline material in these samples might also be organic carbon. In Sample 128-799B-53R-CC, 9-11 cm, burrows that are filled with siliceous carbonate (dolomite) exhibit a dark brown stain that we have interpreted as organic carbon (Pl. 3, Fig. 2).

\section{TEXTURES AND MICROSTRUCTURES}

\section{Grain Size and Shape}

Most of the thin sections consist of siliceous claystone made up of clay-sized grains of clay minerals and cryptocrystalline silica. The siliceous claystones typically have less than $5 \%$ angular silt grains that are randomly scattered throughout the section, plus infrequent sand grains. Sections having bedding in hand samples contain thin, very fine, silt to fine, sand-sized grains in layers 1 to $5 \mathrm{~mm}$ thick. These layers contain angular to subangular quartz, feldspar grains, and rounded glauconite grains.

\section{Preferred Orientation}

Within the lithified portion of Hole 799B, the clay grains exhibit a strong preferred orientation (PI. 1, Fig. 1) that defines a semipenetrative foliation. This fabric can be identified by rotating the thin section under crossed nicols: at certain orientations, the entire section will brighten or darken as a unit. Use of a calcite plate enhances this effect, causing the entire section to change color during rotation. Where bedding, defined by textural changes (grain size and shape), is visible in the claystones, it is parallel to the foliation.

The preferred orientation of clay grains also is expressed by subparallel to parallel alignment of a number of other features. Fossils and diatom "ghosts" are typically partially flattened along the foliation, as in Plate 2, Figure 2. Streaks of phosphatic material and stringers of pyrite framboids formed during diagenesis are also aligned with the clay mineral foliation (Pl. 4, Fig. 4).

The preferred orientation of the clay minerals is most likely a result of rotation and recrystallization during compaction and dewatering of the sediments. Independent support for this hypothesis is provided by the flattening of fossil diatoms and sponges that were originally round.

\section{Compaction Structures}

Although alignment of diagenetic minerals, such as phosphate and pyrite, is probably due to their deposition along primary bedding planes, additional flattening probably occurred during compaction of the sediments. In the sandstones, compaction features include broken and bent plant fragments and phosphatic claystone clasts that have 
been squeezed into shapes conformable with the surrounding quartz clasts. "F-phosphate" nodules and stringers have been indented by sand and silt grains (Pl. 5, Fig. 1), and detrital mica and biotite grains have been bent as a result of compaction where they are in contact with quartz grains. Aligned clay particles can be observed to wrap around quartz silt grains. In several thin sections, panels of clay particles have been rotated relative to adjoining panes of grains as a result of differential compaction around a noncompressive grain (Pl. 5, Fig. 4).

Differential compaction is also visible in sand layers where soft fibrous plant material has been deposited with quartz and feldspar sand grains. This plant material has been deformed and penetrated by the less compressible sand grains.

To a large extent, the bedding/foliation structure controlled the fractures that developed during the release of high gas pressure in the cores when they were brought to atmospheric conditions on board the ship. These irregular fractures are subparallel to each other, as well as to bedding and foliation. In at least one case, one of the large, flattened fossil sponges appears to have controlled the location of a fracture.

\section{Porosity and Permeability}

Most of the porosity observed in these samples was caused by expansion and fracturing during the release of overpressured gas. Thus, porosity figures obtained from specimens do not represent porosity of the rock at depth. Within the siliceous claystones, almost no porosity was observed; within the sandstones, porosity was low to very low.

Except for a few of the sands and sandstones, the sediments and sedimentary rocks of Hole 799B are characterized by low permeability. The best evidence of this is the difficulty experienced when vacuum impregnating the nonlithified samples with a low-viscosity epoxy resin.

\section{SUMMARY AND CONCLUSIONS}

Shore-based petrographic examination of samples from each major lithologic unit cored by ODP on all legs should be undertaken routinely. Our preliminary study of only a few thin sections resulted in several new observations of the lithology and mineralogy that permit a reevaluation of shipboard observations. Most important is the recognition that much of the interval "altered vitric tuff" between 981.17 and $1002.41 \mathrm{mbsf}$ is variable in lithology and that much of the tuffaceous material consists of reworked volcanic material having a substantial sedimentary component.

Another significant discovery is the carbonate cement in the sandstone at 1061.35 mbsf (Appendix), a feature previously unrecognized. Although we did not consider the study of sandstones to be a major part of this project, our preliminary observations demonstrate the variability of these sandstones and suggest that further study would be productive.

\section{Diagenetic Sequence}

Both "F-phosphate" and pyrite occur as flattened stringers and streaks parallel to foliation. In rare cases, round phosphate grains cut across the foliation. If we assume that the flattening of these diagenetic minerals occurred during compaction of the sediments, then they must have formed soon after the sediments were deposited. The round grains of "D-phosphate" and the glauconites having weathered rims, some of them broken, must represent very hard grains that were transported as silt and sand and that subsequently resisted flattening during compaction. Irregular glauconite grains having indistinct boundaries that do not show flattening must have formed in-situ but after compaction. Observations such as these, and others described above, permit us to propose the following diagenetic sequence for the deeper portion of Hole 799B:
1. hard round "D-phosphate," phosphatic fish teeth and bones, and glauconite grains were transported and deposited with the sediments and remained stable during diagenesis;

2. "F-phosphate" streaks and pyrite framboids;

3. clay minerals;

4. rotation, flattening, and compaction; and

5. in-situ glauconite grains.

At present, no concrete evidence exists as to the timing of development of the silica nodules and carbonate concretions, except that they pre-date the compaction.

\section{ACKNOWLEDGMENTS}

We thank the student assistants, Chris Rudnick and Katherine Ouzt, and also Kyung-ho Lee, who worked hard on sample preparation. We thank the Department of Geoscience, University of NevadaLas Vegas, for their hospitality during our sabbatical leave.

\section{REFERENCES}

Garrison, R.E., and Kastner, M., 1990. Phosphatic sediments and rocks recovered from the Peru margin during ODP Leg 112. In Suess, E., von Huene, R., et al., Proc., ODP, Sci. Results, 112: College Station, TX (Ocean Drilling Program), 111-134.

Shipboard Scientific Party, 1990a. Explanatory notes. In Ingle, J. C., Jr., Suyehiro, K., von Breymann, M. T., et al., Proc., ODP, Init. Repts., 128: College Station, TX (Ocean Drilling Program), 39-64.

1990b. Site 799. In Ingle, J. C., Jr., Suyehiro, K., von Breymann, M. T., et al., Proc., ODP, Init. Repts., 128: College Station, TX (Ocean Drilling Program), 237-402.

Swartz, J. F., and Lindsley-Griffin, N., 1990. An improved impregnation technique for studying structure of unlithified cohesive sediments. In Suess, E., von Huene, R., et al., Proc., ODP, Sci. Results, 112: College Station, TX (Ocean Drilling Program), 87-91.

Date of initial receipt: 7 March 1991

Date of acceptance: 22 November 1991

Ms 127/128B-112

\section{APPENDIX}

\section{Summary of Thin-Section Data}

In the descriptions below, "clay-rich pelite" signifies pelite composed of microcrystalline clay and isotropic to subisotropic diagenetic silica in roughly equal proportions. "Silica-rich pelite" signifies pelite composed of isotropic to subisotropic diagenetic silica, with minor microcrystalline clay. "Clay-bearing siliceous pelite" signifies pelite composed of isotropic to subisotropic diagenetic silica, with about $30 \%$ microcrystalline clay. "Silica" signifies isotropic to subisotropic silica.

Percentages are based on point counts of 100 to 300 points of petrographic thin sections, with more points counted for the more variable lithologies. Where no percentages are given, components are listed in approximate order of importance, with the most common constituent first.

\section{Sample 128-799B-33R-1, 73-76 cm. 750.93 mbsf. Siliceous claystone.}

Clay-rich pelite (54\%); silica-rich pelite (33\%); silt (3\%, total); authigenic minerals $(10 \%$, total $)$.

Silt: angular to subangular grains of quartz $(2 \%)$, with calcareous foraminifers (1\%), feldspar (tr), glauconite (tr), "D-phosphate" nodules (tr).

Authigenic minerals: "F-phosphate" nodules (6\%), pyrite framboids (4\%).

Weak fabric defined by optically subparallel orientation of clay minerals and laminae of phosphate nodules, pyrite framboids, concentrations of silicarich claystone.

Sample 128-799B-33R-3, 24-27 cm. 753.44 mbsf. Siliceous siltstone.

Angular to subangular silt grains in a matrix of siliceous claystone. 
Silt: quartz, with minor feldspar, siltstone, strained feldspar, glauconite.

Authigenic minerals in the matrix include " $\mathrm{F}$-phosphates" and phosphateenriched matrix, pyrite framboids.

Very weak fabric defined by optically subparallel clay minerals in the matrix, flattened "F-phosphate" nodules.

\section{Sample 128-799B-34R-2, 34-36 cm. 761.64 mbsf. Silty siliceous claystone.}

Clay-rich pelite; silica-rich pelite; silt.

Silt: angular to subangular grains of quartz, with minor rock fragments (siltstone), chlorite?, feldspar, glauconite, "D-phosphate" nodules.

Authigenic minerals: "F-phosphate" nodules and pyrite framboids.

Very weak fabric defined by parallel alignment of flattened "F-phosphates" and stringers of pyrite framboids, optically subparallel clay minerals.

\section{Sample 128-799B-34R-3, 3-5 cm. 762.83 mbsf. Dolomite.}

Microcrystalline to cryptocrystalline dolomite mixed with cloudy diagenetic silica (52\%); clear microcrystalline dolomite $(48 \%)$.

Trace amounts of microfossils, some with pyrite framboids filling them, and trace amounts of scattered pyrite framboids.

No bedding or other fabric.

\section{Sample 128-799B-35R-1, 61-63 cm. 770.11 mbsf. Silty siliceous claystone} with burrows and a fossil sponge.

Clay-rich pelite (44\%); silica-rich pelite $(41 \%)$; silt (5\%, total); authigenic minerals ( $10 \%$, total).

Angular to subangular silt grains consist of quartz (5\%), with minor siltstone (tr), glauconite (tr), "D-phosphate" nodules (tr), feldspar (tr).

Authigenic minerals include pyrite framboids $(5 \%)$, phosphate-enriched siliceous pelite (5\%), "F-phosphate" nodules (tr).

Moderate fabric defined by optically subparallel clay minerals aligned with "F-phosphate" nodules and stringers of pyrite framboids. Burrows filled with clay are slightly flattened; a single crushed and flattened fossil sponge,

Sagarites makiyama (or Makiyama titanni), was observed.

\section{Sample 128-799B-36R-1, 48-50 cm. 779.68 mbsf. Siliceous claystone.}

Clay-rich pelite; silica-rich pelite; silt.

Silt: angular to subangular grains of quartz with minor feldspar, glauconite, "D-phosphate" nodules.

Authigenic minerals: "F-phosphate" nodules, pyrite framboids. Sparse siliceous microfossils are outlined by pyrite framboids and filled with phosphate.

Strong fabric defined by optically subparallel clay minerals, and parallel alignment of flattened "F-phosphates" and stringers of pyrite framboids.

\section{Sample 128-799B-37R-1, 30-31 cm. 789.20 mbsf. Porcellanite with burrows.}

Silica-rich pelite $(45 \%)$, clay-bearing siliceous pelite $(40 \%)$; silt $(3 \%$, total); authigenic minerals ( $12 \%$, total).

Silt: angular to subangular grains of quartz $(3 \%)$ with minor glauconite (tr), "D-phosphate" nodules (tr), diatoms (tr).

Authigenic minerals: pyrite framboids (5\%), "F-phosphate" nodules $(3 \%)$ and glauconite (tr). Burrows are filled with diagenetic silica and minor clay $(4 \%)$.

Moderate fabric defined by "F-phosphates," pyrite framboid stringers, and optically subparallel clay minerals.

\section{Sample 128-799B-39R-CC, 3-5 cm. 809.27 mbsf. Silty siliceous claystone} with burrows.

Clay-rich pelite; silica-rich pelite; silt.

Silt: angular to subangular grains of quartz with minor feldspar, glauconite, "D-phosphate" nodules.

Authigenic minerals: phosphate-enriched matrix, "F-phosphate" nodules, pyrite framboids. Phosphatic material is better developed around burrows.

Burrows are filled with diagenetic silica, clay, and pyrite framboids and are surrounded by concentrations of dark brown phosphate-enriched silica.

Moderate fabric defined by "F-phosphates," pyrite framboid stringers, and optically subparallel clay minerals. Burrows are flattened parallel to the fabric.
Sample 128-799B-46R-4, 132-134 cm. 881.12 mbsf. Porcellanite.

Silica-rich pelite $(62 \%)$; clay-bearing siliceous pelite $(25 \%)$; silt $(1.7 \%$, total); authigenic minerals ( $11.3 \%$, total).

Silt: angular to subangular grains of quartz (1.3\%) with minor feldspar (tr), "D-phosphate" nodules (tr), rock fragments (siltstone, $0.4 \%$ ), phosphatic pelagic debris (tr).

Authigenic minerals: phosphate-enriched silica (6.3\%), pyrite framboids (5\%), "F-phosphate" nodules (tr).

Well-developed layering defined by laminae of clay-rich pelite and by flattened phosphate and pyrite nodules. Moderate fabric defined by optically subparallel clay minerals.

Sample 128-799B-48R-2, 22-24 cm. 896.32 mbsf. Siltstone with a sandstone microturbidite.

\section{Siltstone}

Angular to subangular silt-sized grains in a matrix of clay-rich pelite, silica-rich pelite.

Clasts: quartz with minor glauconite, feldspar.

Authigenic minerals in matrix: diffuse phosphate-enriched siliceous pelite, "F-phosphate" nodules, pyrite framboids.

Well-developed layering defined by changes in grain size and composition. Moderate fabric defined by flattened phosphates and pyrite stringers and by optically subparallel clay minerals.

\section{Sample 128-799B-50R-1, 83-85 cm. 914.43 mbsf. Siliceous claystone.}

Clay-rich pelite; silica-rich pelite; silt.

Silt: angular to subangular grains of quartz with minor feldspar, glauconite, "D-phosphate" nodules, microfossils.

Authigenic minerals: phosphate-enriched matrix, "F-phosphate" nodules, pyrite framboids.

Moderate fabric defined by "F-phosphates," pyrite framboid stringers, and optically subparallel clay minerals. Crushed and flattened siliceous forms may be fossil sponges.

Sample 128-799B-50R-3, 74-76 cm. 917.34 mbsf. Siliceous claystone, intensely burrowed.

Clay-rich pelite; silica-rich pelite; silt.

Silt: angular to subangular grains of quartz with minor feldspar, glauconite, "D-phosphate" nodules, and a possible phosphate peloid with concentric structure that is slightly flattened.

Authigenic minerals: phosphate-enriched matrix, "F-phosphate" nodules, pyrite framboids. Burrows are filled with cloudy subisotropic silica or with siliceous pelite.

Poorly defined bedding indicated by change in proportion of silica and clay. Moderate fabric defined by flattened "F-phosphates," pyrite framboid stringers, burrows, and optically subparallel clay minerals. A clay-filled fracture or vein parallel to the bedding is surrounded by a reddish-brown siliceous solution front.

Sample 128-799B-51R-2, 57-59 cm. 925.35 mbsf. Siliceous claystone and silty porcellanite.

\section{Siliceous Claystone}

Clay-rich pelite (46\%); silica-rich pelite (44\%); silt ( $24 \%$, total); authigenic minerals $(7.6 \%$, total).

Silt: angular to subangular grains of quartz $(1.6 \%)$ with minor feldspar $(0.4 \%)$, "D-phosphate" nodules (tr), phosphatic pelagic debris $(0.4 \%)$.

Authigenic minerals: phosphate-enriched matrix (3.3\%), "F-phosphate" nodules $(1.6 \%)$; framboidal pyrite dots and stringers $(2.7 \%)$.

\section{Silty Porcellanite}

Silica-rich pelite (38\%); clay-rich pelite $(30 \%)$; silt (19\%, total); authigenic minerals ( $13 \%$, total).

Silt: angular to subangular grains of quartz (17\%), with minor glauconite (1\%), rock fragments (chert, siltstone, 1\%), feldspar (tr), "D-phosphate" nodules (tr).

Authigenic minerals: phosphate-enriched siliceous pelite $(5 \%)$, "Fphosphate" nodules $(5 \%)$, pyrite framboids $(3 \%)$. 
Poorly defined bedding indicated by changes in proportions of silica and clay and by a silty layer $1 \mathrm{~mm}$ thick. Moderate fabric defined by flattened "F-phosphates," pyrite framboid stringers, and optically subparallel clay minerals. In the claystone, flattened silica-cored nodules rimmed with phosphate and carbonate may represent recrystallized fossil sponges.

Sample 128-799B-51R-4, 57-59 cm. 928.37 mbsf. Siliceous claystone with burrows.

Clay-rich pelite; silica-rich pelite; silt.

Silt: angular to subangular grains of quartz with minor feldspar, "Dphosphate" nodules, phosphatic pelagic debris.

Authigenic minerals: phosphate-enriched matrix, "F-phosphate" nodules, framboidal pyrite dots and stringers. Burrows are filled with carbonate (dolomite) and subisotropic silica.

Poorly defined bedding indicated by changes in proportions of silica and clay. Moderate fabric defined by flattened "F-phosphates," pyrite framboid stringers, burrows, and optically subparallel clay minerals.

Sample 128-799B-52R-1, 32-33 cm. $933.22 \mathrm{mbsf}$. Siliceous claystone with fossil sponges.

Clay-rich pelite; silica-rich pelite; silt.

Silt: angular to subangular grains of quartz with minor "D-phosphate" nodules, glauconite, phosphatic pelagic debris.

Authigenic minerals: phosphate-enriched matrix, "F-phosphate" nodules, framboidal pyrite dots and stringers; layer of carbonate (dolomite) and subisotropic silica.

Poorly defined bedding indicated by changes in proportions of silica and clay. Moderate fabric defined by flattened "F-phosphates," pyrite framboid stringers, and optically subparallel clay minerals. Fossil sponges Sagarites makiyama (or Makiyama titanni) are also flattened parallel to bedding.

\section{Sample 128-799B-52R-2, 90-91 cm. 935.30 mbsf. Silty dolomitic} claystone.

Clay-rich pelite; silica-rich pelite; siliceous carbonate; silt.

Silt: angular to subangular grains of quartz with minor "D-phosphate" nodules, glauconite, phosphatic pelagic debris.

Authigenic minerals: phosphate-enriched matrix, "F-phosphate" nodules, framboidal pyrite dots and stringers; layer of carbonate (dolomite) and subisotropic silica. A siliceous carbonate has a cloud of phosphate-enriched pelite around it.

Poorly defined bedding indicated by changes in proportions of silica and clay. Strong fabric defined by optical orientation of clay minerals, and enhanced by flattened "F-phosphate" nodules, pyrite framboid stringers. A flattened area of microcrystalline silica probably represents a crushed and recrystallized fossil sponge.

Sample 128-799B-53R-CC, 9-11 cm. $944.65 \mathrm{mbsf}$. Siliceous claystone and dolomite with fossil sponges and burrows.

Clay-rich pelite; silica-rich pelite; siliceous carbonate; silt.

Silt: angular to subangular grains of quartz with minor "D-phosphate" nodules, glauconite, phosphatic pelagic debris, sponge spicules.

Authigenic minerals: phosphate-enriched matrix, "F-phosphate" nodules, framboidal pyrite dots and stringers; nodules of siliceous dolomite. Burrows are filled with siliceous carbonate (dolomite), apparently stained with organic matter.

Bedding indicated by changes in grain size as well as in proportions of silica, clay, and carbonate. Strong fabric defined by optical orientation of clay minerals and enhanced by flattening of "F-phosphate" nodules, pyrite framboid stringers, burrows, and sponges.

Sample 128-799B-54R-1, 25-27 cm. 952.45 mbsf. Silty siliceous claystone with carbonate-filled burrows or concretions and a fossil sponge.

Clay-rich pelite; silica-rich pelite; siliceous carbonate; silt.

Silt: angular to subangular grains of quartz with minor "D-phosphate" nodules, phosphatic pelagic debris, sponge spicules, glauconite.

Authigenic minerals: phosphate-enriched matrix, "F-phosphate" nodules, framboidal pyrite dots and stringers; nodules of siliceous dolomite. Burrows are filled with siliceous carbonate (dolomite), apparently beginning to recrystallize into concretions.
Bedding indicated by changes in grain size as well as in proportions of silica, clay, and carbonate. Strong fabric defined by optical orientation of clay minerals and enhanced by flattening of "F-phosphate" nodules, pyrite framboid stringers, burrows or concretions, and sponges.

Sample 128-799B-55R-1, 39-41 cm. 962.19 mbsf. Siliceous claystone with phosphate-rich and carbonate-rich layers, carbonate-filled burrows.

Clay-rich pelite; silica-rich pelite; carbonate-rich pelite; phosphatic porcellanite; silt.

Silt: angular to subangular grains of quartz with minor feldspar, glauconite, "D-phosphate" nodules, phosphatic pelagic debris.

Authigenic minerals: phosphate consisting of "F-phosphate" nodules and phosphate-enriched siliceous pelite; carbonate concretions; pyrite framboids. Burrows are filled with siliceous carbonate.

Fabric is defined by strong preferred orientation of clay minerals, enhanced by compaction flattening of phosphate and pyrite nodules, and by pyrite stringers. Bedding defined by change in grain size as well as by compositional changes (phosphate, carbonate, silica). One bed has several carbonate-filled burrows as well as carbonate concretions.

\section{Sample 128-799B-55R-2, 51-53 cm. 963.81 mbsf. Siliceous claystone.}

Clay-rich pelite; silica-rich pelite; silt.

Silt: angular to subangular grains of quartz with minor rock fragments (siltstone), "D-phosphate" nodules, phosphatic pelagic debris.

Authigenic minerals: phosphate-enriched matrix, "F-phosphate" nodules; framboidal pyrite dots and stringers; minor carbonate concretions.

Weak fabric defined by parallel orientation of clays and compaction of "F-phosphate" nodules and pyrite stringers.

Sample 128-799B-56R-1, 67-69 cm. 972.17 mbsf. Pelletal porcellanite and claystone.

Silica-rich pelite, clay-rich pelite, silt.

Silt: angular to subangular grains of quartz with minor rock fragments (siltstone), "D-phosphate" nodules, phosphatic pelagic debris.

Authigenic minerals: phosphate-enriched matrix, "F-phosphate" nodules; framboidal pyrite dots and stringers; minor carbonate concretions.

Moderate fabric defined by parallel orientation of clays and compaction of "F-phosphate" nodules and pyrite stringers.

\section{Sample 128-799B-56R-2, 121-123 cm. 974.21 mbsf. Silty claystone.}

Clay-rich pelite, with minor siliceous clay zones, silt.

Silt; angular and subangular quartz with minor polycrystalline quartz grains; "D-phosphate" nodules, glauconite.

Authigenic minerals: minor amounts of "F-phosphate" nodules, pyrite framboids, clots, and stringers.

Parallel orientation of clay particles. Silica-rich clay-filled burrows are flattened parallel to compaction fabric.

Sample 128-799B-57R-1, 15-16 cm. 981.25 mbsf. Siliceous claystone with dolomite concretions, fossil sponges.

Clay-rich pelite, silica-rich pelite, dolomite-rich pelite, silt.

Silt: angular to subangular grains of quartz with minor rock fragments (siltstone), feldspar, chlorite, "D-phosphate" nodules, phosphatic pelagic debris. Authigenic minerals: phosphate-enriched matrix, "F-phosphate" nodules; framboidal pyrite dots and stringers; minor carbonate concretions.

Strong fabric defined by parallel orientation of clays and compaction of "F-phosphate" nodules and pyrite stringers; flattening of concretions and fossil sponges Sagarites makiyama (or Makiyama titanni).

Sample 128-799B-57R-1, 75-77 cm. 981.85 mbsf. Siliceous claystone from interval identified as "altered vitric tuff" in Site 799 chapter of Initial Reports volume (Shipboard Scientific Party, 1990b).

Clay-rich pelite $(69 \%)$; silica-rich pelite $(23 \%)$; authigenic minerals; authigenic minerals ( $8 \%$, total).

Silt: no silt observed. 
Authigenic minerals: total phosphate (5\%) [phosphate-enriched siliceous clay $(3 \%)$, "F-phosphate" nodules $(1.5 \%)$, pelagic phosphate $(0.5 \%)$, "D-phosphate" nodules (tr)]; pyrite framboids ( $3 \%$ ).

Well-developed fabric exhibited by optically subparallel clays. Compaction features lacking, as are flattened "F-phosphates" and framboidal pyrite nodules; pyrite framboids are single isolated dots and small clots.

\section{Sample 128-799B-58R-1, 13-15 cm. $990.93 \mathrm{mbsf}$. Silty porcellanite from interval identified as "altered vitric tuff" in site report.}

Silica-rich pelite ( $65 \%)$; silica ( $21 \%)$; silt $(9 \%$, total); authigenic minerals $(5 \%$, total).

Silt: angular to subangular grains of quartz $(7 \%)$ with minor rock fragments (siltstone or chert, $1 \%)$, feldspar $(0.5 \%)$, biotite (tr), glauconite $(0.5 \%)$, "D-phosphate" nodule (tr), opaque (tr).

Authigenic minerals: dolomite $(3 \%)$, phosphate (enriched matrix and pelagic, $1 \%)$, pyrite framboids $(1 \%)$.

Layering is defined by relatively clay-rich zones ("silica-rich pelite") interbedded with silica. Clay minerals are optically parallel to bedding.

\section{Sample 128-799B-58R-1, 62-64 cm. 991.42 mbsf. Dolomitic porcellanite, possibly derived by alteration and reworking of vitric tuff.}

Silica ( $59 \%)$; silica and microcrystalline dolomite (39\%); silt ( $2 \%$, total). Silt: quartz (1\%), feldspar (tr), opaque (1\%).

Authigenic minerals: "F-phosphate" nodule (tr).

Fabric is lacking because no clay minerals are present. No bedding or lamination observed.

\section{Sample 128-799B-59R-1, 50-52 cm. $1001.00 \mathrm{mbsf}$. Altered vitric tuff.}

Subisotropic silica.

Authigenic minerals: possible pyrite framboids.

No fabric. Brown to dark brown isotropic glass shards are distributed throughout the section.

\section{Sample 128-799B-60R-2, 20-22 cm. $1011.90 \mathrm{mbsf}$. Siliceous claystone.}

Clay-rich pelite; silica-rich pelite; silt.

Silt: angular to subrounded grains of quartz with minor feldspar, glauconite, "D-phosphate" nodules, rock fragments (claystone, chert), chlorite, phosphatic pelagic debris and a possible phosphate peloid.

Authigenic minerals: phosphate consisting of "F-phosphate" nodules and phosphate-enriched siliceous pelite; pyrite framboids.

Fabric consists of a strong preferred orientation of the clay minerals, parallel to bedding and compaction features. Bedding is defined by changes in proportions of silica-rich to clay-rich pelite and by changes in amount of silt from layer to layer. Compaction features include flattened "F-phosphate" nodules and stringer of pyrite framboids.

\section{Sample 128-799B-60R-4, 26-28 cm. 1014.96 mbsf. Siliceous claystone.}

Clay-rich pelite; silica-rich pelite; silt (quartz).

Authigenic "F-phosphate" nodules and phosphate-enriched siliceous pelite; pyrite framboids.

\section{Sample 128-799B-61R-1, 50-52 cm. $1020.30 \mathrm{mbsf}$. Siliceous claystone with layers of porcellanite and sandstone.}

\section{Claystone}

Clay-rich pelite; silica-rich pelite; silt.

Silt: angular to subrounded grains of quartz with minor feldspar, glauconite, "D-phosphate" nodules, rock fragments (siltstone, chert, quartzite), phosphatic pelagic debris.

Authigenic minerals: phosphate consisting of "F-phosphate" nodules and phosphate-enriched siliceous pelite; pyrite framboids as small dots, clots, and stringers; glauconite with indistinct grain boundaries.

\section{Porcellanite}

Silica-rich pelite; clay-bearing siliceous pelite; silt (same as claystone).

\section{Sandstone}

Poorly sorted, angular to subangular grains, with rare subround to round grains, cemented with isotropic brown material (hematite-stained silica?). No porosity observed.

Clasts include quartz, feldspar (plagioclase), glauconite, rock fragments (siltstone, claystone, volcanic glass, quartzite, chlorite schist).

Fabric in the claystone and porcellanite is defined by preferred orientation of clay minerals and by phosphate nodules and pyrite stringers parallel to bedding.

\section{Sample 128-799B-61R-4, 55-57 cm. 1024.84 mbsf. Sandstone.}

Clasts $(70 \%$, total), matrix (16\%), cement (14\%).

Poorly sorted, angular to subangular grains, with rare subround grains, in matrix of siliceous claystone, isotropic brown cement (hematite-stained silica?). Matrix contains isolated pyrite framboids and phosphate. No porosity observed.

Clasts include quartz (44\%), feldspar (10\%), siltstone (5\%), pyritic "F-phosphate" (3\%), glauconite ( $2 \%)$, volcanic glass-some with flow banding $(2 \%)$, organic material $(2 \%)$, silica nodules $(2 \%)$, chlorite schist $(1 \%)$, dolomite (1\%), "D-phosphate" nodules (tr). Rock fragments present in trace amounts include pyritic siltstone, claystone, phosphatic claystone, pelletal phosphate, porcellanite, quartzite (metamorphic fabric of recrystallized, sutured quartz grains). Organic material is fibrous, dark brown to black, probably plant debris.

Some of the bright green glauconite clasts have yellow-brown rims extending partly around their edges, suggesting weathering followed by transport. Some, but not all, glauconite grains have framboidal pyrite in their cores.

Fabric defined by subparallel orientation of long axes of grains enhanced by compaction. Compaction features include broken and bent plant fragments and phosphatic claystone clasts that have been squeezed into shapes conformable with the surrounding quartz clasts.

Sample 128-799B-61R-5, 80-82 cm. 1026.60 mbsf. Siliceous claystone.

Clay-rich pelite; silica-rich pelite; silt.

Silt: angular to subrounded grains of quartz with minor feldspar, glauconite, "D-phosphate" nodules, rock fragments (claystone), chlorite?, phosphatic pelagic debris and siliceous pellets.

Authigenic minerals: phosphate consisting of "F-phosphate" nodules and phosphate-enriched siliceous pelite; pyrite framboids. A group of two or three foraminifers forms the core of a small calcareous concretion.

Fabric is defined by strong preferred orientation of clay minerals, enhanced by compaction flattening of phosphate and pyrite nodules, and by pyrite stringers.

\section{Sample 128-799B-62R-1, 43-45 cm. 1029.93 mbsf. Siliceous claystone and mudstone.}

\section{Claystone}

Clay-rich pelite; silica-rich pelite; silt.

Silt: angular to subrounded grains of quartz with minor feldspar, glauconite, "D-phosphate" nodules, rock fragments (claystone), phosphatic pelagic debris.

Authigenic minerals: phosphate consisting of "F-phosphate" nodules and phosphate-enriched siliceous pelite; pyrite framboids, siliceous dolomite concretion containing pyrite framboids.

\section{Mudstone}

Poorly sorted, angular to subangular silt-sized and rare sand-sized grains in siliceous clay matrix.

Clasts include quartz, feldspar (plagioclase), glauconite, rock fragments (claystone), "D-phosphate" nodules.

Authigenic minerals: phosphate consisting of "F-phosphate" nodules and phosphate-enriched siliceous pelite; pyrite framboids, trace of calcite in matrix. 
Fabric is defined by strong preferred orientation of clay minerals, enhanced by compaction flattening of dolomite, phosphate and pyrite nodules, and by pyrite stringers.

Sample 128-799B-62R-4, 56-58 cm. $1034.56 \mathrm{mbsf}$. Siliceous claystone, with layers of pyrite-cemented sandstone, dolomitic claystone, and phosphatic porcellanite.

Claystone

Clay-rich pelite $(61 \%)$; silica-rich pelite $8 \%)$; silt (10\%, total); authigenic minerals $(21 \%$, total).

Silt: angular to subrounded grains of quartz $(8.5 \%)$, with minor feldspar $(0.5 \%)$, glauconite (tr), "D-phosphate" nodules $(1 \%)$, phosphatic pelagic debris (tr).

Authigenic minerals: phosphate consisting of "F-phosphate" nodules and phosphate-enriched siliceous pelite $(15 \%)$; pyrite framboids $(6 \%)$.

Fabric is defined by strong preferred orientation of clay minerals, enhanced by compaction flattening of phosphate and pyrite nodules, and by pyrite stringers. Bedding is defined by layers of sandstone, dolomitic claystone, and phosphatic porcellanite.

Sandstone

Clasts (50\%), phosphatic matrix (23\%), pyrite cement (27\%).

Poorly sorted, angular to subangular grains, in matrix of phosphate-enriched siliceous claystone, cement of framboidal pyrite. No porosity observed.

Clasts include quartz (27\%), claystone ( $8 \%$ ), siltstone (7\%), feldspar (5\%), pyritic "F-phosphate" nodules $(2 \%)$, chlorite schist $(1 \%)$, glauconite (tr), dolomite (tr), "D-phosphate" nodules (tr), quartzite (tr).

Sample 128-799B-63R-1, 42-44 cm. 1039.52 mbsf. Siliceous claystone and siliceous dolomite.

\section{Claystone}

Clay-rich pelite; silica-rich pelite; silt

Silt: angular to subrounded grains of quartz with minor feldspar, glauconite, "D-phosphate" nodules, rock fragments (claystone, siltstone), chlorite, phosphatic pelagic debris.

Authigenic minerals: phosphate consisting of "F-phosphate" nodules and phosphate-enriched siliceous pelite; pyrite framboids.

\section{Dolomite}

Microcrystalline dolomite with clouds of subisotropic silica, minor clays, silt (quartz), pelagic phosphate, authigenic "F-phosphate," pyrite framboids.

Fabric is defined by strong preferred orientation of clay minerals, enhanced by compaction flattening of phosphate and pyrite nodules and by pyrite stringers. Bedding is defined by claystone and dolomite layers.

Sample 128-799B-63R-3, 46-47 cm. 1042.56 mbsf. Siliceous claystone with a microturbidite layer of sandy silt.

\section{Claystone}

Clay-rich pelite (62\%); silica-rich pelite (23\%); silt ( $9 \%$, total); authigenic minerals $(6 \%$, total).

Silt: angular to subangular grains of quartz $(8 \%)$ and feldspar (tr), glauconite (tr), "D-phosphate" nodules (tr), phosphatic pelagic debris ( $1 \%$ ).

Authigenic minerals: phosphate consisting of "F-phosphate" nodules and phosphate-enriched siliceous pelite $(3 \%)$; pyrite framboids ( $3 \%$ )

Fabric is defined by strong preferred orientation of clay minerals, enhanced by compaction flattening of phosphate and pyrite nodules and by pyrite stringers.

\section{Sandy Silt Layer}

Sandy silt layer is a microturbidite with graded bedding.
Sand: quartz grains (36\%); polycrystalline quartz grains ( $9 \%$ ); pelite grains $(10 \%)$; feldspar grains $(5 \%)$, mica grains $(5 \%)$; carbonate pellets $(1 \%)$; hornblende grain (tr); glauconite (1\%); crushed sponge (tr).

Matrix: siliceous claystone (24\%); pyrite ( $9 \%$ ).

Fabric: microturbidite layer is parallel to preferred orientation of clay minerals within the claystone. Long axes of sand grains are not parallel to layering, thus indicating that sand layer was dumped and was not compacted.

\section{Sample 128-799B-64R-1, 86-88 cm. 1049.66 mbsf. Siliceous claystone} with carbonate and phosphate-enriched laminae, fossil sponges.

Clay-rich pelite; silica-rich pelite; phosphate-rich pelite, carbonate, silt.

Silt: angular to subangular grains of quartz with minor feldspar, rock fragments (chert or siltstone), glauconite, chlorite, "D-phosphate" nodules, phosphatic pelagic debris.

Authigenic minerals: phosphate consisting of "F-phosphate" nodules and phosphate-enriched siliceous pelite; pyrite framboids, glauconite. Pyrite is more abundant in the phosphatic layer.

Fabric is defined by strong preferred orientation of clay minerals, enhanced by compaction flattening of phosphate and pyrite nodules and by pyrite stringers. Bedding is defined by layers of pyritic claystone, phosphatic claystone, dolomitic claystone, and claystone with small carbonate concretions. Several crushed and recrystallized sponges are parallel to the fabric.

Sample 128-799B-65R-2, 145-147 cm. 1061.35 mbsf. Sandstone with calcite cement with a single layer of phosphate-rich silty claystone.

Clasts, claystone matrix, calcite cement.

Poorly sorted, angular to subangular grains, in matrix of phosphatic siliceous claystone, cement of calcite.

Clasts include quartz, feldspar, rock fragments (claystone, siltstone), chlorite, glauconite, "D-phosphate" nodules, "F-phosphate" nodules, pyritic phosphate nodule, pelagic phosphate.

Authigenic minerals in the matrix and cement include phosphate, pyrite.

Bedding defined by the interbed of phosphate-rich silty claystone. The "F-phosphate" nodules were soft when deposited as they have been crushed and indented by adjoining grains.

Sample 128-799B-66R-2, 67-70 cm. $1069.36 \mathrm{mbsf}$. Silty claystone with intensely crushed and recrystallized fossil sponges.

Clay-rich pelite (29); silica-rich pelite (10\%); phosphate-enriched clay $(30 \%)$; silt $(17 \%$, total); authigenic minerals $(14 \%$, total).

Silt: angular to subangular grains of quartz ( $10 \%)$ with minor feldspar $(1 \%)$, glauconite (tr), mica $(0.5 \%)$, rock fragments (siltstone, claystone) $(5.5 \%)$, silica nodules (tr), "D-phosphate" nodules (tr), phosphatic pelagic debris (tr).

Authigenic minerals: phosphate consisting of well-developed "F-phosphate" nodules (4\%) and phosphate in phosphate-enriched siliceous pelite; pyrite framboids (10\%)

Fabric is defined by strong preferred orientation of clay minerals, enhanced by compaction flattening of phosphate and pyrite nodules and by pyrite stringers. Some phosphate-pyrite stringers are bent around silt grains. Sponges are intensely crushed and recrystallized; one is bent around silt grains.

\section{Sample 128-799B-67R-2, 122-124 cm. 1080.42 mbsf. Silty phosphatic} claystone.

Clay-rich pelite $(55.5 \%)$; phosphate-rich pelite $(21 \%)$; silica-rich pelite $(11.5 \%)$; silt $(6.5 \%$, total); authigenic minerals (5.5\%, total).

Silt: angular to subangular, rarely subround, grains of quartz (3.5\%) with minor feldspar $(0.5 \%)$, chlorite (tr), rock fragments (claystone, quartzite) $(2 \%)$, "D-phosphate" nodules (tr), phosphatic pelagic debris (tr), siliceous microfossil fragment (tr).

Authigenic minerals: phosphate consisting of "F-phosphate" nodules $(1.5 \%)$ and the phosphate within the phosphate-enriched siliceous pelite; pyrite framboids $(4 \%)$.

Fabric is defined by strong preferred orientation of clay minerals, enhanced by compaction flattening of phosphate and pyrite nodules and by pyrite stringers. 


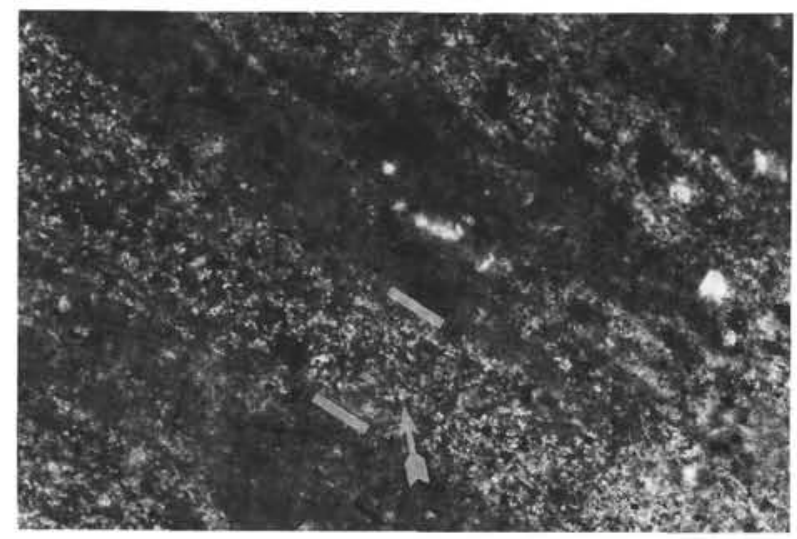

1

$\overline{100 \mu \mathrm{m}}$

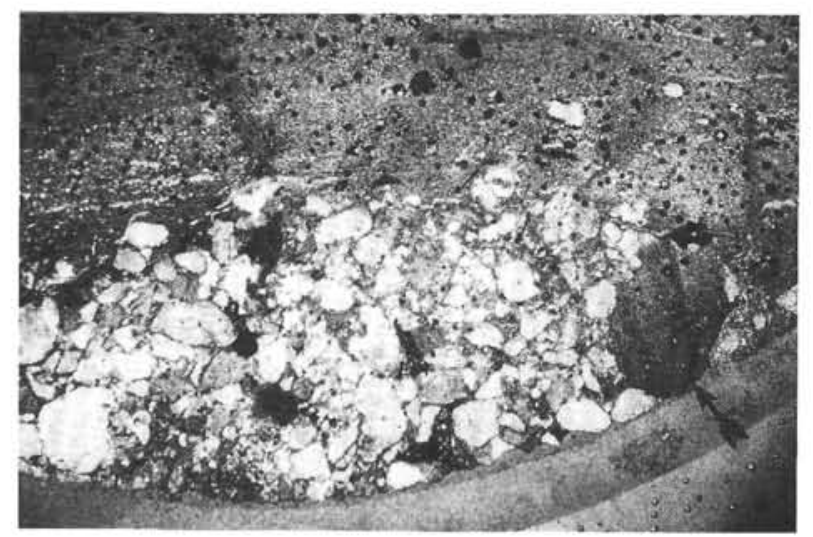

3


4

Plate 1. Photomicrographs of typical lithologies. 1. Clay-rich laminate (identified by two parallel white bars and white arrow) interbedded with silica-rich laminae. Semi-isotropic silica is amorphous to cryptocrystalline, presumably derived from siliceous micro fossils during diagenesis (Sample 128-799B-53R-CC, 9-11 cm) [crossed nicols with gypsum plate]. 2. Pelletal porcellanite with phosphatic pelagic fish fragment (black arrow) (Sample 128-799B-56R-1, 67-69 cm) [crossed nicols with gypsum plate]. 3. Microturbidite sand bed in siliceous claystone and porcellanite. A clast of reworked siliceous claystone is visible at right of bed (black arrow); other clasts are quartz, feldspar, siltstone, and glauconite (Sample 128-799B-61R-1, 50-52 cm) [plane light]. 4. Subrounded to subangular clastic silt grains (white arrow) in "altered vitric tuff" of sedimentary origin (Sample 128-799B-58R-1, 13-15 cm) [crossed nicols]. 




1

$\overline{100 \mu \mathrm{m}}$

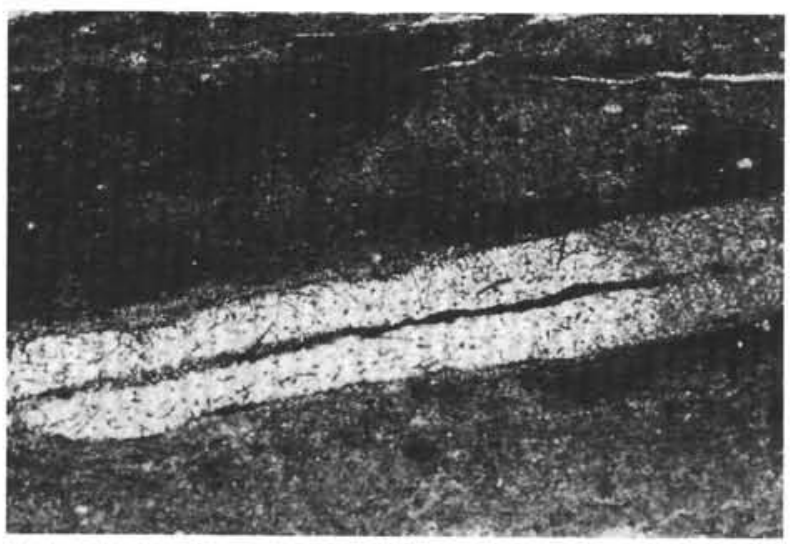

3

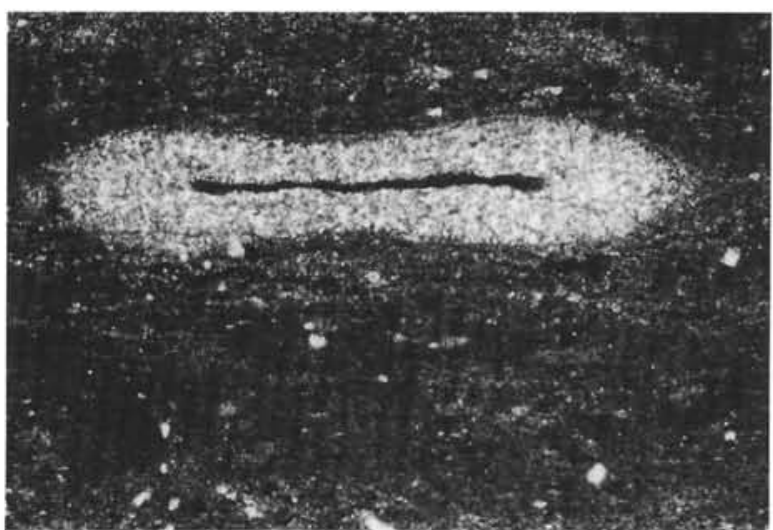

2

$\overline{250 \mu \mathrm{m}}$

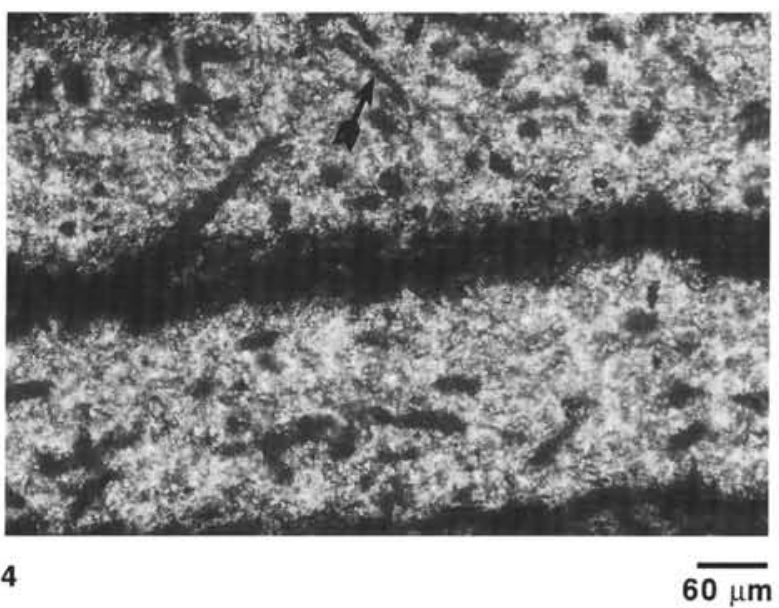

Plate 2. Photomicrographs of fossil sponges. 1. Fossil sponge Sagarites makiyama (or Makiyama titanni), surrounded by a rim of clay enriched in "F-phosphate" and framboidal pyrite (white arrow) (Sample 128-799B-53R-CC, 9-11 cm) [plane light]. 2. Crushed fossil sponge Sagarites makiyama (or Makiyama titanni) in siliceous claystone. Center cavity of sponge is enriched in "F-phosphate". Light zone around sponge contains silt grains, which may be relict agglutinate (Sample 128-799B-53R-CC, 9-11 cm) [plane light]. 3. Fossil sponge Sagarites makiyama (or Makiyama titanni). Center cavity is enriched in "F-phosphate" (Sample 128-799B-53R-CC, 9-11 cm) [plane light]. 4. Closeup of fossil sponge Sagarites makiyama (or Makiyama titanni) in Plate 2, Figure 3. Relict spicules (black arrow) can be clearly seen in this well-preserved example (Sample 128-799B-53R-CC, 9-11 cm) [plane light]. 




1

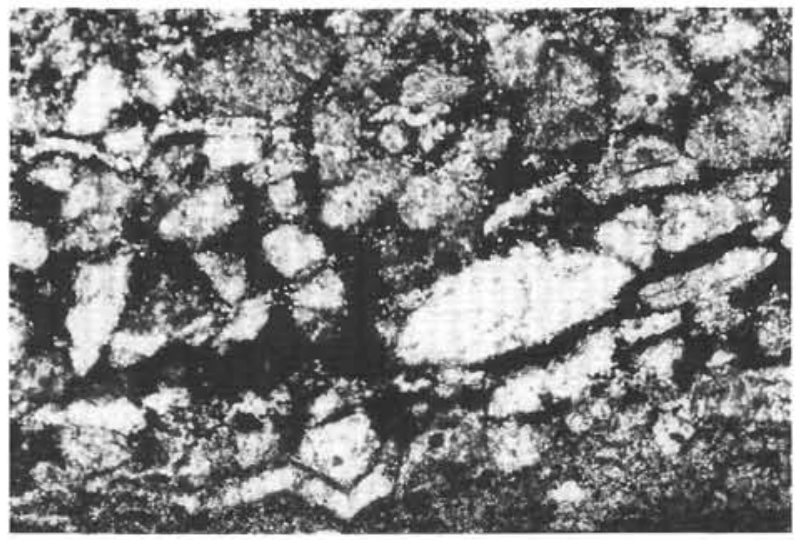

3

$100 \mu \mathrm{m}$



2

$10 \overline{100 \mathrm{~m}}$

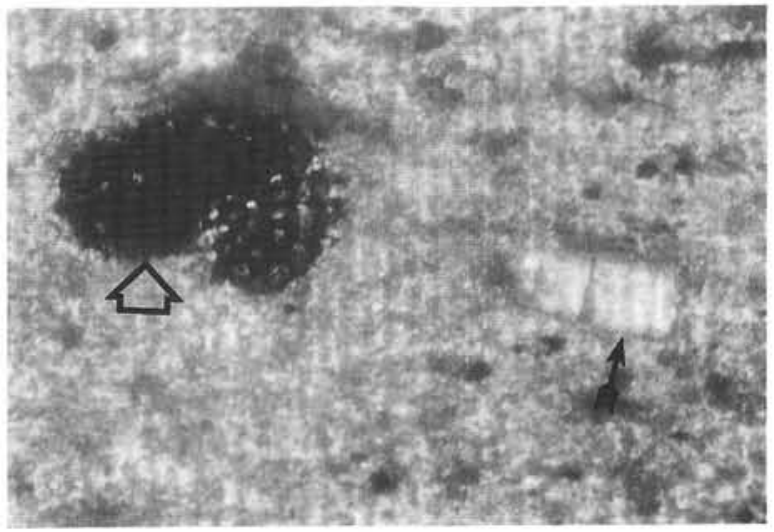

4

Plate 3. Photomicrographs of diagenetic silica and pyrite. 1. Hard nodule of diagenetic silica (hollow white arrow in center), clot of pyrite framboids (black arrow, lower right), and laminations of authigenic "F-phosphate" (white arrow, above and below silica). Silica nodule is 325 to $425 \mathrm{~m}$ across (Sample 128-799B-33R-1, 73-76 $\mathrm{cm}$ ) [plane light]. 2. Burrows (hollow white arrow) in siliceous claystone. Burrow fill consists of diagenetic carbonate and silica colored by dark brown to black organic material. In the claystone matrix, laminae are defined by stringers of "F-phosphates" and pyrite framboids (white arrow) (Sample 128-799B-53R-CC, 9-11 cm) [plane light]. 3. Microturbidite bed of sand grains cemented by framboidal pyrite (Sample 128-799B-62R-4, 56-58 cm) [crossed nicols]. 4. Diatom replaced by framboidal pyrite (hollow black arrow). Silt grain at right is feldspar (black arrow) (Sample 128-799B-37R-1, 30-31 cm) [plane light]. 


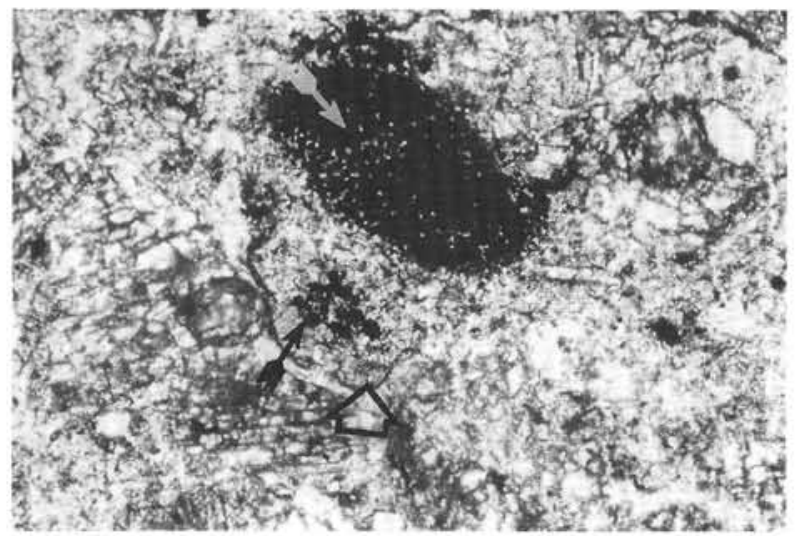

1

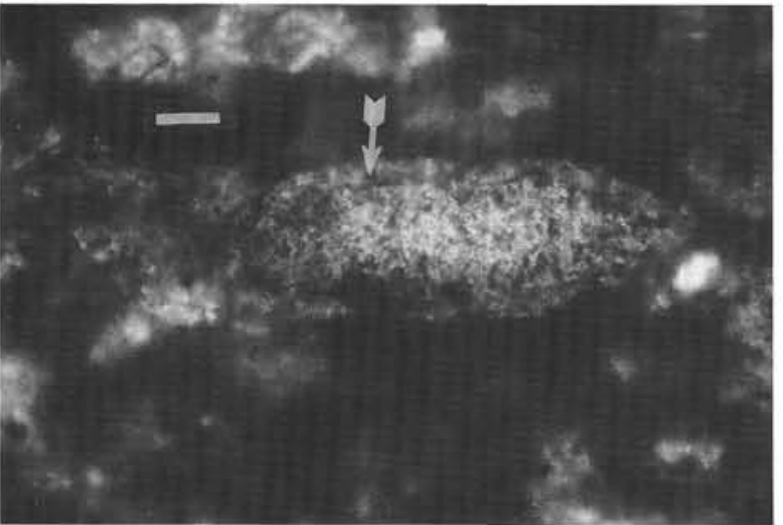

$60 \mu \mathrm{m}$

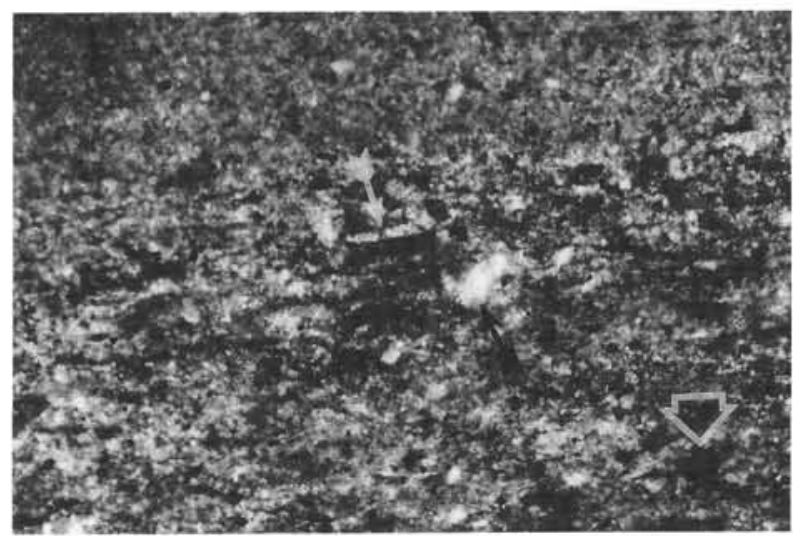

2

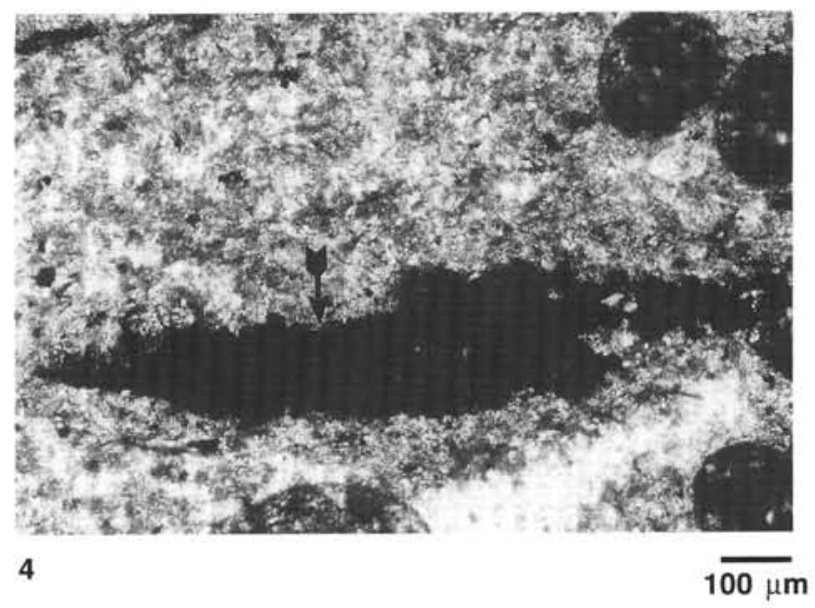

Plate 4. Photomicrographs of phosphates. 1. Glauconite grain (hollow black arrow, lower center) and pyritic phosphate nodule (white arrow, upper center) in sandstone. Glauconite has pyrites framboids (black arrow) in its core, and is circled by an incomplete weathered rim (dark in this photo). The phosphate nodule consists of a cluster of phosphate pellets and pyrite framboids; its rounded character suggests it is transported rather than autochthonous (Sample 128-799B-61R-4, $55-57 \mathrm{~cm}$ ) [plane light]. 2. Pelagic phosphate (fish tooth?) in left center (white arrow); "D-phosphate" nodule in lower right corner (hollow white arrow, nodule appears black in photo). Dark area around fish debris and the bright quartz Coast (black arrow) is phosphate-enriched siliceous pelite (Sample 128-799B-54R-1, $25-27 \mathrm{~cm}$ ) [plane light]. 3. Phosphate nodule that exhibits concentric structure (white arrow) suggestive of peloidal origin; its slight elongation parallel to bedding (bedding orientation indicated by white bar) indicates it was not completely hard when compaction occurred. Size of phosphate nodule $=169-494 \mu \mathrm{m}$ (Sample 128-799B-50R-3, 74-76 cm) [plane light]. 4. Nodule of "F-phosphate" and pyrite framboids (black arrow) in siliceous claystone. Irregular outline, indistinct boundary, and flattened shape of nodule suggest that it is autochthonous. Large, round, dark objects are bubbles (Sample 128-799B-61R-1, 50-52 cm) [plane light]. 




1

$\overline{100 \mu \mathrm{m}}$

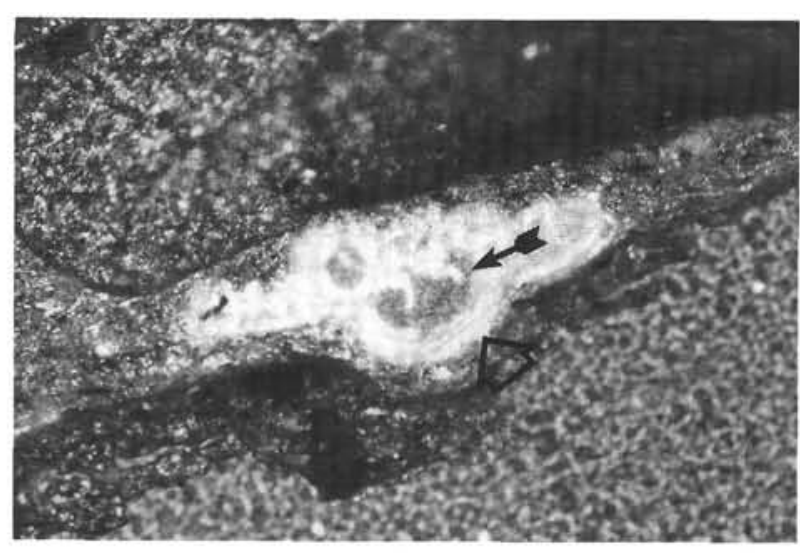

3

$\overline{100 \mathrm{~m}}$

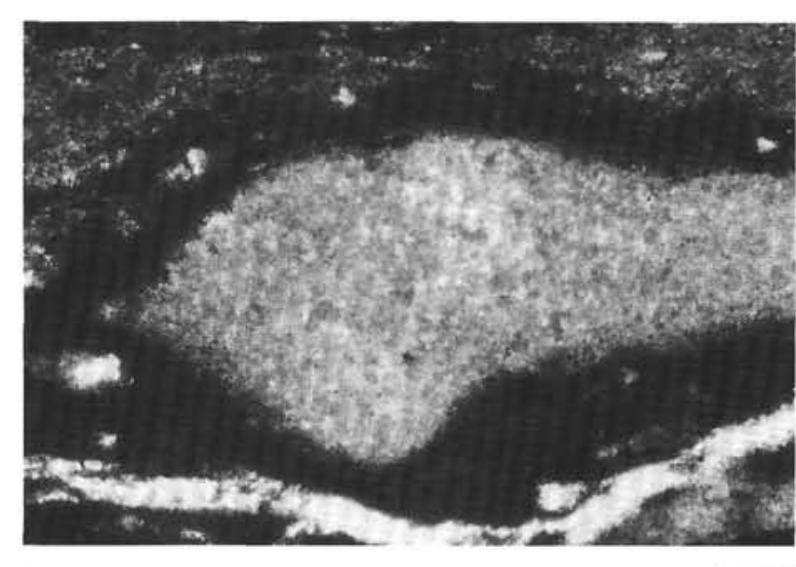

2

$10 \overline{0 \mathrm{~m}}$

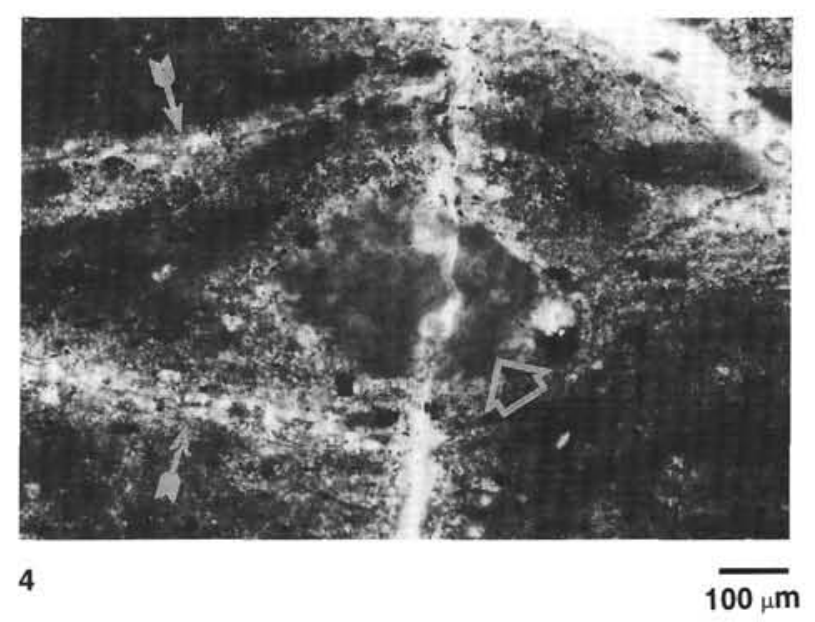

Plate 5. Photomicrographs of structures. 1. Long, thin "F-phosphate" nodule (open black arrow) crushed and bent around sand grains (black arrow, feldspars grain). Large, round, dark objects are bubbles (Sample 128-799B-66R-2, 67-70 cm) [plane light]. 2. Microscopic concretion of carbonate in dark brown sediment of diagenetic silica and phosphate (Sample 128-799B-57R-1, 15-16 cm) [plane light]. 3. Carbonate concretion (hollow black arrow) around foraminifers (black arrow). Circular features on either side of concretion are bubbles where epoxy did not penetrate sample thoroughly (Sample 128-799B-61R-5, 80-82 cm) [crossed nicols]. 4. Diagenetic silica nodule in silty siliceous claystone (hollow white arrow). Clay minerals (white arrows) around the nodule formed before compaction was complete. During compaction, packets of clays rotated on both sides of the thickest part of the nodule, as shown by the bright claystone layers wrapping around the nodule. Bright vertical line in center is a scratch in the thin section (Sample 128-799B-33R-1, 73-76 cm) [plane light]. 